\title{
Drug use Among Pregnant Females Attending a Rural Family Health Unit- Dakahlia Governorate, Egypt
}

\author{
Safaa A Badr, ${ }^{1}$ Nora A Khalil, ${ }^{2}$ Saadia M El-Said ${ }^{3 *}$ \\ ${ }^{1}$ Public Health and Community Department, Faculty of Medicine, Menoufia University \\ ${ }^{2}$ Family Medicine Department, Faculty of Medicine, Menoufia University \\ ${ }^{3}$ Family Medicine Department, Faculty of Medicine, Menoufia University
}

\begin{abstract}
:
Background: Drug use during pregnancy is prevalent, with 44-99\% of women being prescribed medication during pregnancy. The use of medication in pregnancy is often necessary for the treatment of acute and chronic illness. Objectives: The aim of this study was to assess the frequency of medication use (prescribed $\alpha$ non prescribed)among pregnant ladies that attending rural health unit in Mansoura district, Dakahlia Governorate. Methods: A cross-sectional study was conducted on 350 pregnant ladies that attending the rural family health unit, Mansoura district, Dakahlia Governorate during the period from 1st of January to December 2017. The studied pregnant females were subjected to structured questionnaire to collect data regarding socio-demographic criteria, obstetric history, medical history and history of drug use during pregnancy. Results: The study revealed that the frequency of medication use during pregnancy due to acute and chronic illness was (15\% and $18 \%)$ respectively. The common supplement intake during pregnancy were iron and calcium $(96.2 \%, 96.9 \%)$ respectively. About $(22 \%)$ of the studied pregnant ladies received medication without a doctor's prescription. About $(92 \%)$ of common medication used among pregnant ladies were safe (category B) according to FDA classification of drug.Conclusion: Frequency of medication use for acute and chronic illnesses among pregnant ladies were (15\%) and (18\%) respectively, indicating rational use of drugs among the studied group and (92\%)of the medication used among the studied pregnant ladies were safe (category B) according to FDA classification of drugs.
\end{abstract}

Keywords: Drug use, self medication, supplement, and pregnant ladies.

Introduction: The use of medication in pregnancy is often necessary for the treatment of acute or chronic illnesses. Poor management of maternal diseases can have a negative effect on both the health of the mother and the fetus. ${ }^{(1)}$ About $8 \%$ of pregnant females worldwide need permanent drug treatment; for chronic diseases such as: diabetes, for acute illnesses such as influenza, or for treating pregnancy associated symptoms such as vomiting. ${ }^{(2)}$ The prescription of medications during pregnancy presents a great challenge to the physicians who must consider the risk benefit relation for both the mother and the fetus. ${ }^{(3)}$

Drug use is an uncommon cause of birth defects, but certain medications can increase the likelihood of developing a birth defect. ${ }^{(4)}$ Different studies have shown that most pregnant ladies use either prescribed or over the counter (OTC) drugs and herbal supplements. ${ }^{(5)}$ A physician caring for a pregnant patient who requires 
medication should take care in choosing dosages and types of drugs that maximize effectiveness while minimizing fetal risk. ${ }^{(6)}$

The majority of pregnant ladies use medication during pregnancy, despite increasing availability of information about teratogenic risks, medication use during pregnancy still causes uncertainty and concern among pregnant ladies and their health care providers. ${ }^{(7)}$.To guide safe drug use during pregnancy, U.S.A Food and drug administration (FDA) classified drugs into the following major categories; A, B, C, D, and X with categories D and X indicating evidence of risk in pregnancy. ${ }^{(8,9)}$

Drug utilization research (DUR) studies provide insights into aspects of drug use and drug prescribing. ${ }^{(10,11)}$

These studies provide important indicators of which drugs are most commonly used by pregnant ladies, for which conditions, and whether this use might be problematic for mothers and infants. By identifying frequently used medicines with unknown risks, priorities could be established for epidemiological research. ${ }^{(12)}$ The aim of the study was to assess the frequency of medication (prescribed $\alpha$ non prescribed) drugs used among pregnant ladies attending a rural family health unit in Mansoura district, Dakhalia Governorate, Egypt.

Methods: This study was a descriptive cross sectional study conducted in Shobrahour rural family health unit in Mansoura district, Dakhalia Governorate, Egypt.The study included all pregnant females aged from 16-40 years old attended the selected FHU for antenatal care during the period of data collection from $1^{\text {st }}$ of January to $1^{\text {st }}$ of April 2017, the sample size was calculated used Raosoft online sample size calculator based on the size of studying population (pregnant ladies registered in the selected primary health care unit) and an assumed prevalence of medication us during pregnancy $(50 \%)$ with relative error of $5 \%$ at level of significance of $95 \%$. A sample of (340) females was required to be included in the study and was increased to (350) to avoid data loss. The data were collected by direct interview with pregnant ladies one day per week from 9 am to 2 pm till completing the required sample.

Data was collected from participants using a structured questionnaire, which included the following parts: 
- Socio-demographic and economic data (e.g., age, education, occupation, and the socioeconomic level based on Fahmy et al, 2015 scoring system of families ).

- Obstetric history of the participants, which includes questions on both current and past obstetric history.

- (c)Medical history: To explore the reasons of drug administration during pregnancy either for acute or chronic condition, identify the type of the drug used and duration of administration. For example: intake of vitamins, pain killer, aspirin, drugs for heartburn and other pregnancy symptoms). Also to explore history of selfmedication during pregnancy without medical consultation.

Written consent was taken from each participant and the study was approved by the ethics committee in the Faculty of Medicine, Menoufia University. Statistical presentation and analysis of the present study was conducted by Statistical package of Social Science (SPSS) version 20 (SPSS Inc, Chicago, Illinois, USA). Qualitative data were expressed as number and percentage and analyzed applying the Chi-square test.

Results: The present study showed that $15 \%$ and $18 \%$ of the studied pregnant ladies used medication for acute illness and chronic illness respectively (figure
1\&2). The current study showed that there was a significant difference between participants in different pregnancy trimesters regarding drug intake as iron and calcium supplements was frequently used during $3^{\text {rd }}$ trimester $(96.2 \%, 96.9 \%)$ respectively while folic acid $(60 \%)$ was frequently used during $1^{\text {st }}$ trimester. Antiemetic drugs were frequently used during $1^{\text {st }}$ trimester $(57.1 \%)$. Also, progesterone and aspirin $(54.3 \%, 25.7 \%)$ were frequently used during the $1^{\text {st }}$ trimester (Table 1). About (92) $\%$ of the most common medication used among the studied pregnant ladies, according to FDA classification of drugs were safe (category B) during three pregnancy trimesters (figure 4).

This study showed that $22 \%$ of the studied pregnant ladies received medication without a doctor's prescription (self-medication) (figure 3 ). As regards the use of over the counter medication (OTC), analgesics were most frequently used among selfmedication group (Table 2).

Discussion: In the current study, the pregnant ladies used medication for chronic illness about (18\%), this is similar to the results of Norgard et al, (13) study in Denmark showing that the prevalence of maternal chronic disease 
during pregnancy has increased fourfold, reaching $15.76 \%$ in 2013 . The results of the current study show that the common supplements utilized during pregnancy among the studied participants were e.g. iron and calcium $(91.1 \%, 91.4 \%)$. This is similar to the result obtained by Picciano et al, (14) Study, which declared that $(97 \%)$ of women in the USA took supplements during pregnancy.

This study reported that the most common supplement utilized are iron $\&$ calcium supplements which were more frequently used in $2^{\text {nd }}$ and $3^{\text {rd }}$ trimester (96.2\%, 96.9\%) respectively. This is similar to the result obtained by Reddy et al, (15) in an Indian study who reported that iron was prescribed only to $(2.8 \%)$ women in the $1^{\text {st }}$ trimester $(39.3 \%)$ women in the $2^{\text {nd }}$ trimester and $(50 \%)$ women in the $3^{\text {rd }}$ trimester. This study reported that folic acid was $(60 \%)$ frequently used during $1^{\text {st }}$ trimester. This is similar to the result obtained in China reported by Xing et al, ${ }^{(16)}$ who found that folic acid was more common $(67.7 \%)$ used in the $1^{\text {st }}$ trimester. In the current study, the common nonsupplemental drug utilized during pregnancy were GIT drugs e.g., antiemetic and antacid (31.1\%, 9.1\%) respectively, followed by antibiotics and analgesics $(27.4 \%, 24.6 \%)$ respectively.

This result has come in agreement with Law et al, (17) who reported that the antiemetics, was the most prescribed drug in their study and in Rohra et al, ${ }^{(18)}$ who found the most commonly prescribed drugs to pregnant ladies were antiemetics followed by analgesic, anti-microbial and antacids. It is attributed to that; headache and gastritis are the common physiologic problems during pregnancy. This study reported that antiemetics drugs were commonly used during $1^{\text {st }}$ trimester $(57.1 \%)$ This is similar to the result of Vanessa et al, (19) who found that antiemetics were most commonly prescribed during the first trimester to treat hyperemesis gravidarum or morning sickness.

In the current study, the studied pregnant ladies who received medication without physicians prescription were about (22\%). This is similar to the result of Bercaw et al, (20) which illustrates that $(23 \%)$ of pregnant ladies received medication in the United States of America without physician's prescription. In the current study shows that The US-FDA pregnancy risk classification system 
was used to evaluate the risk levels of drugs prescribed during pregnancy.

The majority of prescribed drugs in the present study were safe, $(92.9 \%)$ of the medication used by the studied women were from category B, followed by $(88.3 \%)$ category A. No woman was prescribed category $\mathrm{X}$ drug. Our study showed lower percentages of prescription of categories D and C including, these two categories are always avoided because they are known to be teratogenic. This is inconsistent with Belay et al, (21) who found that about $(27 \%)$ of drugs prescribed were FDA Category B, followed by category $\mathrm{C}$ and category $\mathrm{A}$ and category $\mathrm{X}$ was never prescribed during any trimester.

In the current study, analgesics were the most common drugs (OTC medications) used from our study participant about (16.9\%) due to most common illnesses for which these medications were used in our study were headache and backache. This is inconsistent with Nordeng et al, ${ }^{(22)}$ who found that the commonly used OTC medications are analgesics, antipyretics during pregnancy in $(5 \%)$ women,

Conclusions: Frequency of medication use for acute and chronic illnesses among the studied pregnant ladies were
(15\%) and (18\%) respectively indicating rational use of drugs among the studied group. The majority of women received supplements during pregnancy that play a pivotal role in the prevention of maternal and child mortality and morbidity. About (92.9) $\%$ of the medication used among the studied pregnant ladies were safe (category B) according to FDA classification of drugs. Prescribers should ensure that optimal medications are used when treating women of childbearing potential with chronic medical disorders.

Conflict of interest: There was no conflict of interest and there were no funding agencies

\section{References:}

1. Lawrence B. Finer, Mia R. Zolna(2011).Unintended pregnancy in the United States: incidence and disparities. Contraception.; $\quad 84: 478$. Available on www.ncbi.nlm.nih.gov.

Accessed on November 2012

2. Bánhidy F, Lowry RB, Czeizel $A E(2005)$. Risk and benefit of drug use during pregnancy. Int $\mathbf{J}$ Med Sci.,; 2(3): 100. Available on www.ncbi.nlm.nih.gov. Accessed on July 2005 
3. Malm $\mathrm{H}$, Martikainen $\mathrm{J}$, Klaukka T, Neuvonen PJ(2003). Prescription drugs during pregnancy and lactation-a Finnish register-based study. Eur J Clin Pharmacol.; 59(2): 12733. Available on www.ncbi.nlm.nih.gov.

Accessed on April 2003

4. Mosley JF 2nd, Smith LL, Dezan MD(2015). An overview of upcoming changes in pregnancy and lactation labeling information. Pharm Pract (Granada). 13 (2):605. Available on www.ncbi.nlm.nih.gov. Accessed on June 2015

5. Temming LA, Cahill AG, Riley LE(2016). Clinical management of medications in pregnancy and lactation. Am J Obstet Gynecol (6):698-702. Available on www.ncbi.nlm.nih.gov. Accessed on Feb 2016.

6. Ramoz LL, Patel-Shori NM(2014). Recent changes in pregnancy and lactation labeling: retirement of risk categories. Pharmacotherapy.. 34 (4):389-95. Available on www.ncbi.nlm.nih.gov.

Accessed on January 2014.
7. Csajka C, Jaquet A, Winterfeld U, Meyer Y, Einarson A, Panchaud A(2017). Risk perception by healthcare professionals related to drug use during pregnancy: a Swiss survey. Swiss Med Wkly.7(144):w13936. Available on www.ncbi.nlm.nih.gov. Accessed on December 2017

8. Diaz, H(2016). Prescription of Medications during Pregnancy: Accidents, Compromises, and Uncertainties.

Pharmacy

Epidemiol Drug Saf.; 15(9): 613-7. Available on www.ncbi.nlm.nih.gov. Accessed on Augest 2016.

9. Andrade SE, Davis RL, Cheetham TC, Cooper WO, Li DK, Amini T, et al(2012). Medication Exposure in Pregnancy Risk Evaluation Program. Matern Child Health J.2012; $16 \quad$ (7): 1349-54. Available on www.ncbi.nlm.nih.gov.

Accessed on October 2012

10. Shalini S, Ravichandran V, Mohanty BK, Dhanaraj SK, Saraswathi R. Review article drug utilization studies - An Overview. International Journal 
of Pharmaceutical Sciences and Nanotechnology., $\quad 2010$; 3(1):803-10. Available on www.ijopp.org/sites/default/files /InJPharPract_10_4_251.

Accessed on December 2017.

11. Truter I. A Review of Drug Utilization Studies and Methodologies. Jordan Journal of Pharmaceutical Sciences., 2008; 1(2): 91-103. Available on www.wjpsonline.org/. Accessed on January 2017

12. Daw JR, Hanley GE, Greyson DL, Morgan SG. Prescription drug use during pregnancy in developed countries: a systematic review. Pharmacoepidemiol Drug Saf., 2011; 20(9): 895-902. Available on www.ncbi.nlm.nih.gov. Accessed on Augest 2012

13. Norgard B, Hundborg $\mathrm{HH}$, Jacobsen BA, Nielsen GL, Fonager K. Disease activity in pregnant women with Crohn's disease and birth outcomes: a regional Danish cohort study. Am J Gastroenterol. 2007;102:1947-54. Available on www.ncbi.nlm.nih.gov.

Accessed on June 2007
14. Picciano MF, McGuire MK. Dietary Supplements during Pregnancy: Need, efficacy and safety. In: Lammi-Keefe CJ, Couch SC, Philipson EH, editors. Handbook of Nutrition and Pregnancy., 2008; 191-214. Available on academic.oup.com/ajen/article. Accessed on December 2008

15. Reddy SB, Patil N, Hinchageri SS, Kamala S. Assessing the pattern of drug use among pregnant women and evaluating the impact of counseling on medication adherence among them. International Research Journal of Pharmacy. 2011;2(8):148-153. Available on www.ncbi.nlm.nih.gov. Accessed on April 2017.

16. Xing XY, Tao FB, Hao JH, Huang K, Huang ZH, Zhu XM, Xu YY, Sun Y. Periconceptional folic acid supplementation among women attending antenatal clinic in Anhui, China: data from a population-based cohort study. Midwifery 2012; 28(3):291-7. Available on www.ncbi.nlm.nih.gov. Accessed on October 2011. 
17. Law R, Maltepe C, Bozzo P, Einarson A. Treatment of heartburn and acid reflux associated with nausea and vomiting during pregnancy. Can Fam Physician. 2010;56(2):143144. Available on www.ncbi.nlm.nih.gov.

Accessed on February.

18. Rohra DK, Das N, Azam SI, Solangi AN, Memon Z, Shaikh AM, Khan NH. Drug prescribing patterns during pregnancy in the tertiary care hospitals of Pakistan: a crosssectional study. BMC Pregnancy Childbirth. 2008;8:24. doi: 10.1186/1471-2393-8-24.

Available on

link.springer.com/article.

Accessed on September 2014

19. LR Vanessa, Kevin. Current Medical Diagnosis and Treatment, 53rdedition, McGraw Hill, New York, 2014; 1577-1629.Available on www.jocpr.com.Accessed on July 2015.
20. Bercaw J, Maheshwari B, Sangi?Haghpeykar $\mathrm{H}$. The use during pregnancy of prescription, over the Counter, and alternative medications among Hispanic women. Birth 2010; 37(3): 211-8. doi: $10.1111 / \mathrm{j} .1523-$

536X.2010.00408.x. Available on www.ncbi.nlm.nih.gov. Accessed on September 2010.

21. Belay M, Kahaliw W, Ergetie Z. Assessment of drug utilization pattern during pregnancy in Adama Referral Hospital, Oromia Region, Ethiopia. Int $\mathbf{J}$ Pharm Sci Res. 2013; 4(5): 1905-11. Available on www.ejmanager.com/mnstemps. Accessed on July 2016.

22. H. Nordeng, G. Jacobsen, B. Nesheim, and A. Eskild, "Drug use in pregnancy among parous Scandinavian women," Norsk Epidemiologi, 2009; 11(1). doi: 10.5324/nje.v11i1.541.Available on www.ncbi.nlm.nih.gov. Accessed on July 2017. 


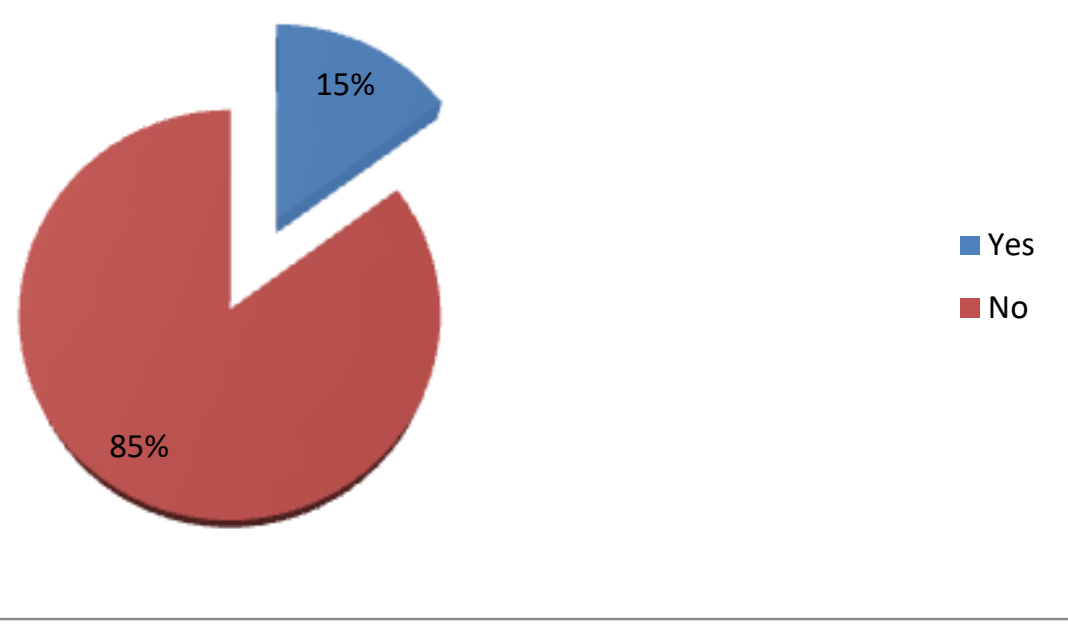

Fig (1): Frequency of medication use during pregnancy due to acute illness

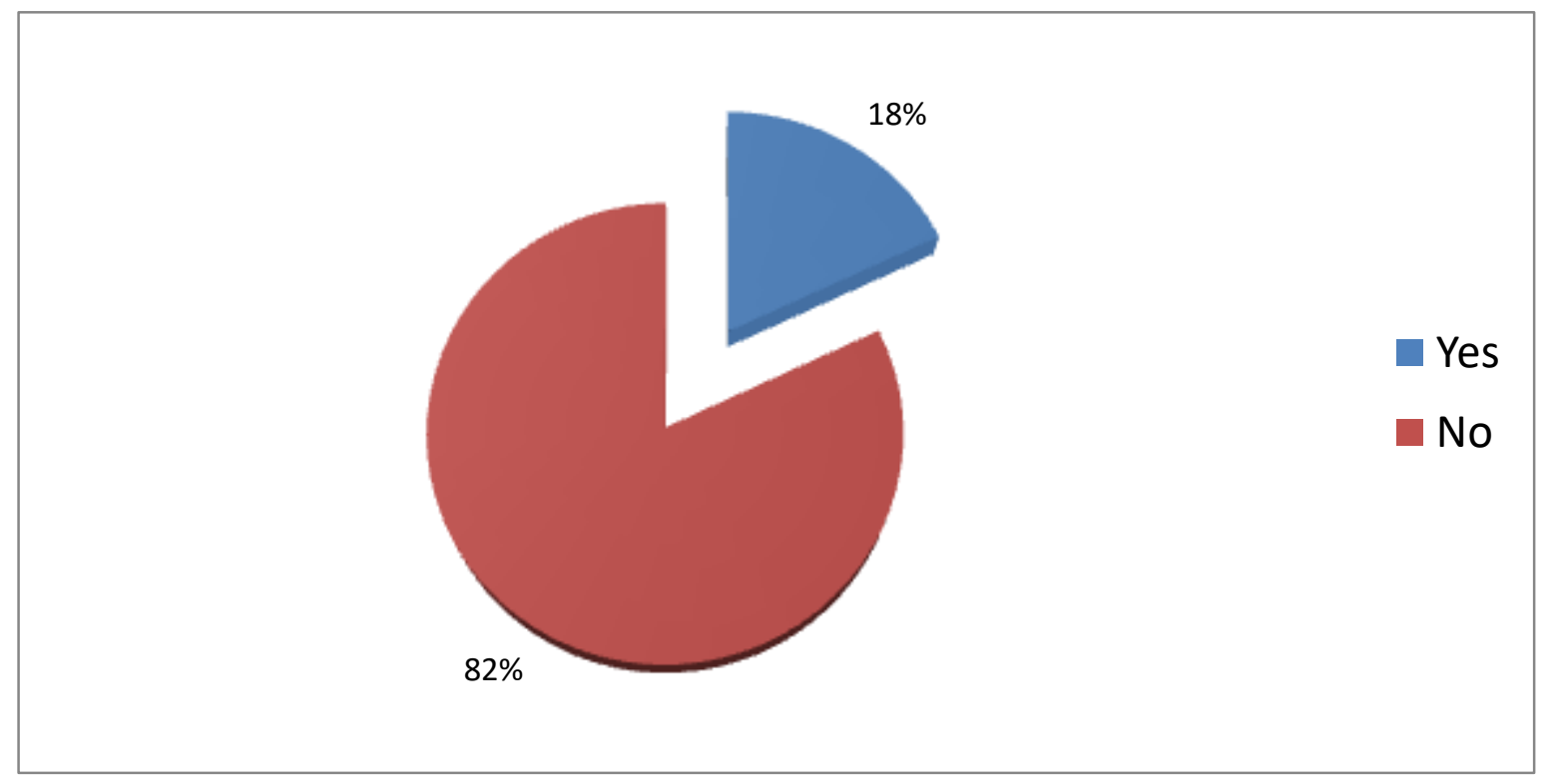

Fig (2): Frequency of medication use during pregnancy due to chronic illness 


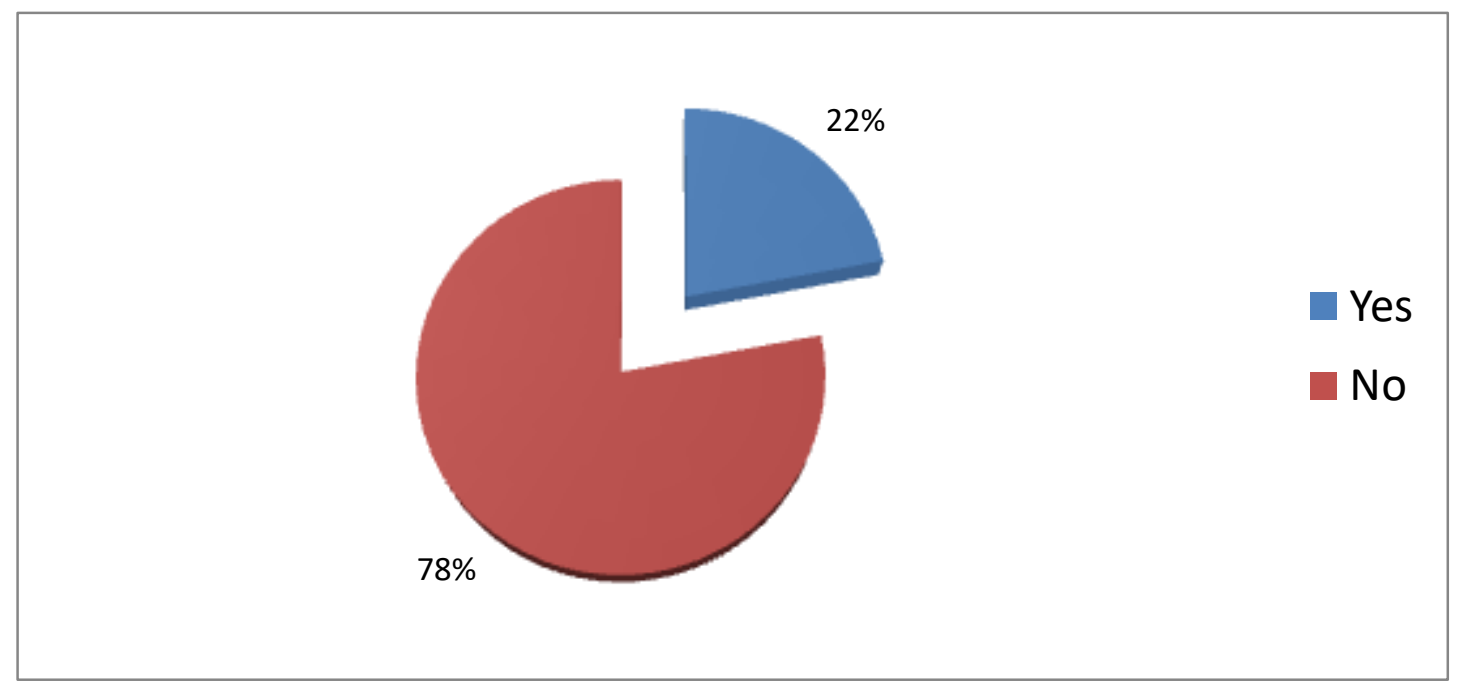

Fig (3): Frequency of Self-medication (non prescribed) during pregnancy 


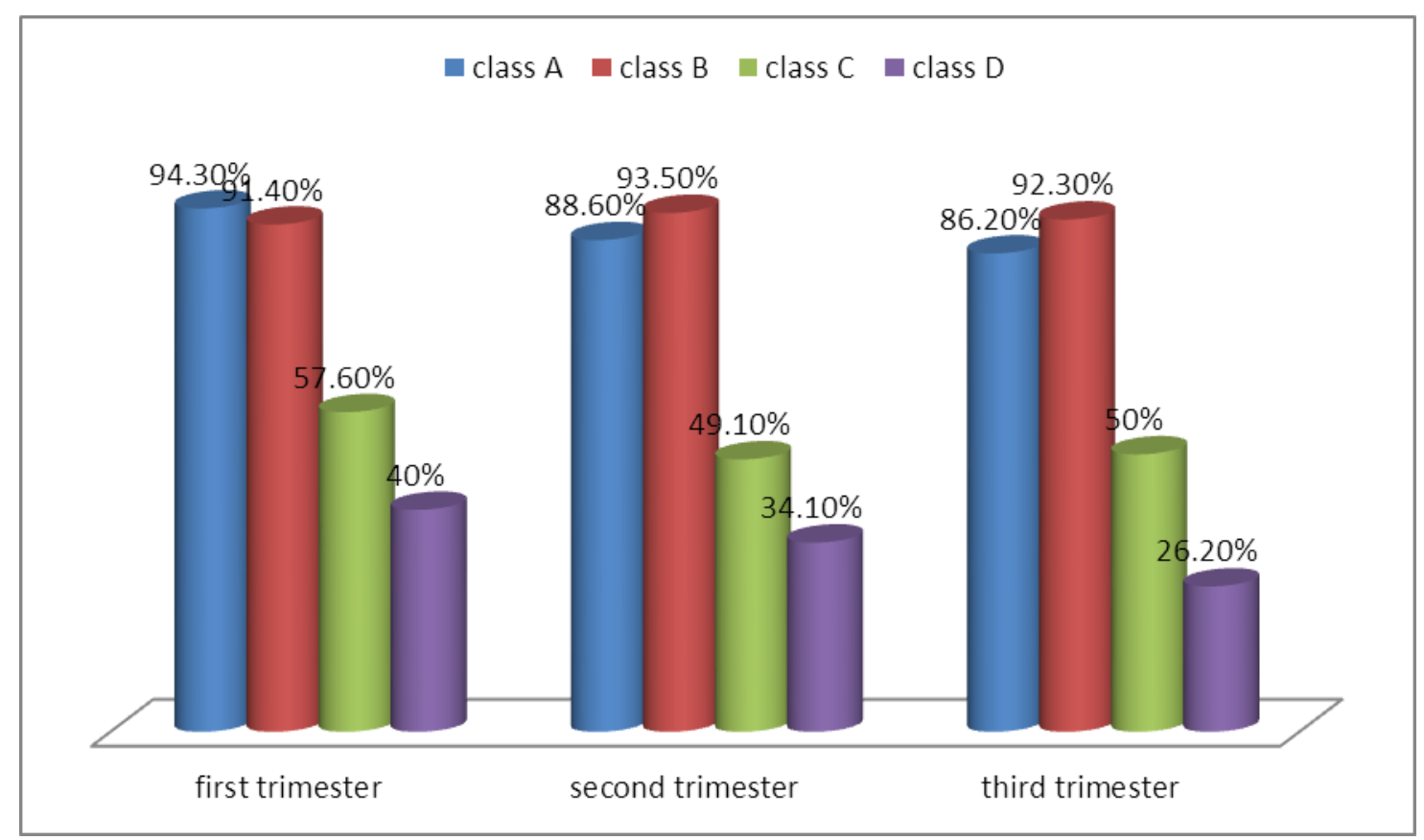

\section{Fig (4): Medications (prescribed and non prescribed) used by pregnant woman according to FDA classification of drugs during three pregnancy trimesters}

Category (A): Adequate and well-controlled studies have failed to demonstrate a risk to the fetus in the first trimester of pregnancy (and there is no evidence of risk in later trimesters).

Category (B): Animal reproduction studies have failed to demonstrate a risk to the fetus and there are no adequate and well-controlled studies in pregnant women.

Category (C): Animal reproduction studies have shown an adverse effect on the fetus and there are no adequate and well-controlled studies in humans, but potential benefits may warrant use of the drug in pregnant women despite potential risks.

Category (D): There is positive evidence of human fetal risk based on adverse reaction data from investigational or marketing experience or studies in humans, but potential benefits may warrant use of the drug in pregnant women despite potential risks. 
Table (1): Frequency of prescribed medication use during pregnancy according to pregnancy trimester

\begin{tabular}{|c|c|c|c|c|c|c|c|c|c|c|}
\hline \multirow[t]{2}{*}{ Item } & \multicolumn{2}{|c|}{$\begin{array}{l}1^{\text {st }} \\
\text { trimester }\end{array}$} & \multicolumn{2}{|c|}{$2^{\text {nd }}$ trimester } & \multicolumn{2}{|c|}{$3^{\text {rd }}$ trimester } & \multicolumn{2}{|l|}{ Total } & \multirow[t]{2}{*}{$\mathbf{X} 2$} & \multirow[t]{2}{*}{$\begin{array}{l}\mathbf{P} \\
\text { value }\end{array}$} \\
\hline & $\begin{array}{l}\text { No } \\
(35)\end{array}$ & $\%$ & $\begin{array}{l}\text { No } \\
(185) \\
\end{array}$ & $\%$ & $\begin{array}{l}\text { No } \\
(\mathbf{1 3 0}) \\
\end{array}$ & $\%$ & $\begin{array}{l}\text { No } \\
(\mathbf{3 5 0}) \\
\end{array}$ & $\%$ & & \\
\hline \multicolumn{11}{|l|}{ Supplement: } \\
\hline - Vitamins & 12 & 34.2 & 51 & 27.6 & 34 & 26.2 & 97 & 27.7 & 0.9 & 0.6 \\
\hline - Iron & 16 & 45.7 & 178 & 96.2 & 125 & 96.2 & 319 & 91.1 & 99.4 & $<0.001$ \\
\hline - Calcium & 16 & 45.7 & 178 & 96.2 & 126 & 96.9 & 320 & 91.4 & 103.8 & $<0.001$ \\
\hline - Folic acid & 21 & 60.0 & 38 & 20.5 & 34 & 26.2 & 93 & 26.6 & 23.5 & $<0.001$ \\
\hline \multicolumn{11}{|c|}{ Gastrointestinal tract Drugs: } \\
\hline - Antiemetics & 20 & 57.1 & 51 & 27.6 & 38 & 29.2 & 109 & 31.1 & 12.4 & 0.002 \\
\hline - Antacid & 8 & 22.9 & 31 & 16.8 & 28 & 21.5 & 67 & 19.1 & 1.5 & 0.5 \\
\hline - Antispasmodics & 10 & 28.6 & 36 & 19.5 & 29 & 22.3 & 75 & 21.4 & 1.5 & 0.5 \\
\hline - $\quad$ Laxatives & 2 & 5.7 & 11 & 5.9 & 12 & 9.2 & 25 & 7.1 & 1.4 & 0.5 \\
\hline \multicolumn{11}{|c|}{ Respiratory Tract Drugs: } \\
\hline - Bronchodilators & 0 & 0.0 & 11 & 5.9 & 14 & 10.8 & 25 & 7.1 & 5.7 & 0.06 \\
\hline - Cough medication & 1 & 2.9 & 22 & 11.9 & 16 & 12.3 & 39 & 11.1 & 2.7 & 0.3 \\
\hline - Antihistamines & 2 & 5.7 & 26 & 14.1 & 16 & 12.3 & 44 & 12.6 & 1.9 & 0.4 \\
\hline \multicolumn{11}{|l|}{ Antimicrobial Drugs: } \\
\hline - Antibiotics & 6 & 17.1 & 52 & 28.1 & 38 & 29.2 & 96 & 27.4 & 2.1 & 0.3 \\
\hline - Antifungal & 0 & 0.0 & 9 & 4.9 & 10 & 7.7 & 19 & 5.4 & 3.4 & 0.2 \\
\hline - Metronidazole & 2 & 5.7 & 11 & 5.9 & 11 & 8.5 & 24 & 6.9 & 0.8 & 0.7 \\
\hline \multicolumn{11}{|l|}{ Others: } \\
\hline - $\quad$ Progesterone & 19 & 54.3 & 39 & 21.1 & 25 & 19.2 & 83 & 23.7 & 20.2 & $<0.001$ \\
\hline - Analgesics & 6 & 17.1 & 48 & 25.9 & 32 & 24.6 & 86 & 24.6 & 1.2 & 0.5 \\
\hline - Antipyretics & 5 & 14.3 & 20 & 10.8 & 21 & 16.2 & 46 & 13.1 & 1.9 & 0.4 \\
\hline - Aspirin & 9 & 25.7 & 18 & 9.7 & 7 & 5.4 & 34 & 9.7 & 12.9 & 0.002 \\
\hline
\end{tabular}


Table (2): Relationship between pattern of drug use and common over the counter medication (OTC) drugs used by the studied pregnant women

\begin{tabular}{|c|l|l|l|l|l|l|}
\hline \multirow{2}{*}{} & \multicolumn{2}{|c|}{$\begin{array}{c}\text { Prescribed } \\
\text { medication (273) }\end{array}$} & \multicolumn{2}{|c|}{$\begin{array}{c}\text { Self-medication } \\
\text { (77) }\end{array}$} & \multicolumn{1}{|c|}{ X2 } & P- \\
value \\
\cline { 2 - 7 } & No & \% & No & $\%$ & \\
\hline - Analgesics & 24 & 8.8 & 13 & 16.9 & 4.2 & 0.04 \\
\hline - Antipyretics & 38 & 13.9 & 8 & 10.4 & 0.7 & 0.3 \\
\hline - Antihistamines & 13 & 4.8 & 7 & 9.1 & 2.1 & 0.1 \\
\hline
\end{tabular}




\section{الملخص العربى \\ إستخدام الأدوية بين النساء الحوامل اللاتي يترددن على عيادة طب الاسرة في منطقة ريفية محافظة الاقهليه ، مصر عل الدئ

$$
\begin{aligned}
& \text { صفاء عبد الفتاح بدر }{ }^{1} \text { ، نورا عبد الهادى خليل2 ، سعديه محمد السيد3 }
\end{aligned}
$$

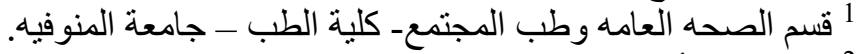

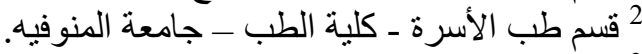

$$
\begin{aligned}
& 3 \text { قسم طب الأسرة ـ كلية الطب لطب - جامعة المنوفيه. }
\end{aligned}
$$

الخلفية: يعد إستخدام الأدويه أثناء الحمل هو مصدر إهتمام عالمي للصحة العامة في كل من البلدان المتقدمة والنامية، حيث ينتشر إستخدام الأدويه بنسبة 44-99 \% بين النساء الحوامل وغالبًا ما يكون إستخدام الأدوية ضروريًا لعلاج الأمراض الحادة والمزمنة أثناء الحمل. الهدف: همدف الدراسة إلى حساب مدى استخدام الادويه لدي السيدات الحوامل (الموصوفه وغير الموصوفه). المنهجية وطرق البحث : أجريت دراسة مستعرضة على 350 إمرأة حامل المترددات على عيادة طب الاسرة في منطقة ريفية بمدينة المنصورة،حافظة الدقهلية خلال الفترة من 1 يناير إلى ديسمبر 2017. خضعت الحوامل المدروسة لاستبيان منظم لجمع البيانات المتعلقة بالمعايير الاجتماعية الديموغرافية ، والتاريخ

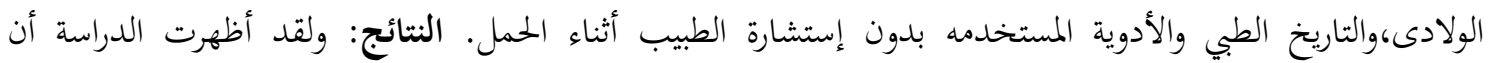

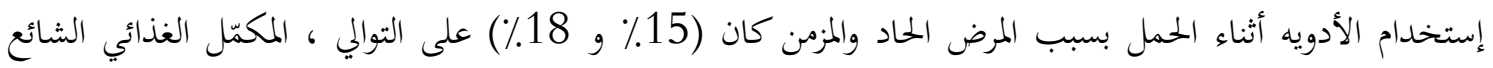

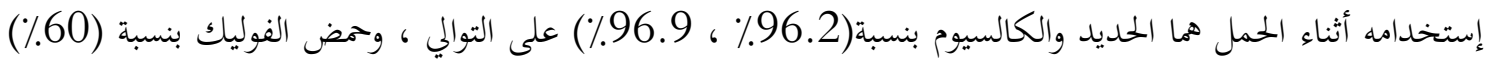

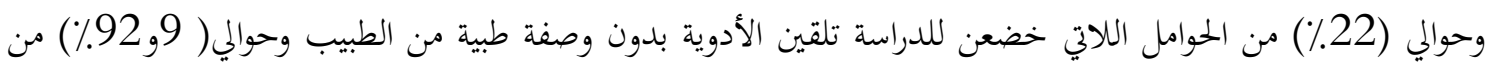

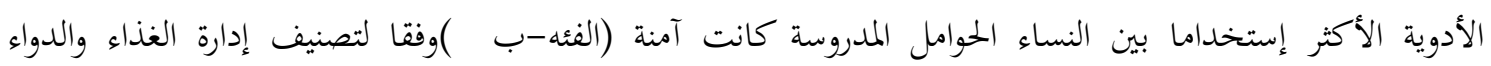

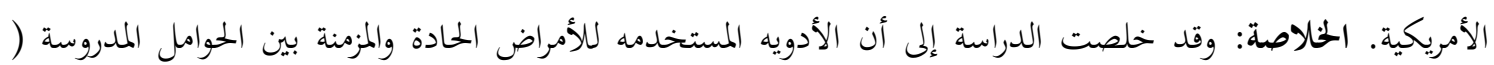

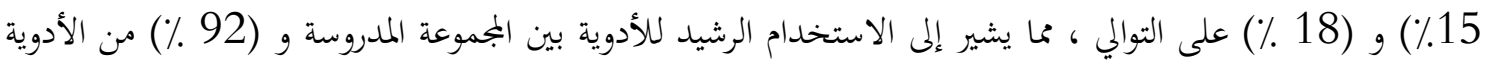

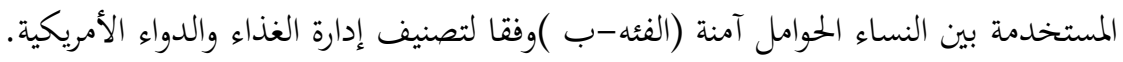

